\title{
Is there IgA of gut mucosal origin in the serum of HIV1 infected patients?
}

\author{
A Quesnel, Ph Moja, F Lucht, J L Touraine, B Pozzetto, C Genin
}

\begin{abstract}
This study was performed in 77 HIV1 seropositive adult patients to characterise the IgA hyperglobulinaemia seen in the serum during the course of HIV infection. It was shown that both IgA1 and IgA2 subclass concentrations were simultaneously increased but the IgA1 increase was predominant. Secretory IgA (SIgA) concentration was significantly increased and $\operatorname{IgA}$ activity to gliadin, bovine serum albumin, and casein could be detected and was correlated with SIgA concentration. In contrast, IgA activity to cytomegalovirus and to tetanus toxoid did not correlate with total IgA concentration. These data suggest the presence of IgA from gut mucosal origin in the serum of these patients. Hyper IgA was inversely correlated with the CD4+ cell number. The increase of all parameters studied varied according to the total IgA concentration in the serum but was also directly related to the stage of immune deficiency in patients with hyper IgA.

(Gut 1994; 35: 803-808)
\end{abstract}

IgA hyperglobulinaemia is a classic immunological abnormality seen in HIV1 disease. ${ }^{1}$ In contrast with IgG concentration, which increases very early during the course of HIV infection, hyper IgA is related to immune defect progress and it has been considered to have a prognostic value. ${ }^{2}$ It is usually assumed that hyperglobulinaemia is consecutive to polyclonal stimulation of immunoglobulins production $^{3}$ by infectious agents especially from the herpes virus group ${ }^{4}$ but also by HIV itself. $^{5}$

Recent data have shown, however, intestinal lesions ${ }^{6}$ with an increase of intestinal mucosal membrane permeability ${ }^{7}$ either secondary to opportunistic germ infection ${ }^{8}$ or occurring earlier during the course of HIV disease directly because of HIV itself. $^{9}$

It was hypothesised that a part of the hyper IgA seen includes IgA from mucosal origin as a consequence of stimulation of the intestinal immune system. The structural characteristics and the activity of IgA to dietary and to non-gut derived antigens were studied and related to the IgA concentration in the serum of $77 \mathrm{HIV}$ seropositive adult patients at different stage of immune deficiency.
Patients and methods

PATIENTS

From a population with sexually or drug transmitted HIV1 infection, we selected 38 patients without immune deficiency (CD4+ cell number higher than $600 / \mathrm{mm}^{3}$ ) and 39 patients with an immune deficiency (CD4+ cell number lower than $400 / \mathrm{mm}^{3}$, and lower than $200 / \mathrm{mm}^{3}$ in 18 of them). They were classified depending on the $\operatorname{IgA}$ concentration in the serum: 32 patients, 28 males and 4 females of mean age 38.5 years ( 22 to 75 ) with hyper IgA (IgA concentration $\geqslant 4.25 \mathrm{~g} / \mathrm{l}$ ) and 45 patients, 35 males and 10 females of mean age 32.6 years (20 to 72) with normal IgA (IgA concentration $<4 \cdot 25 \mathrm{~g} / \mathrm{l})$. One hundred HIV seronegative blood donors from the Centre de Transfusion de Saint-Etienne matched for age and sex were selected as normal controls in each test.

\section{METHODS}

\section{Characterisation of $\operatorname{Ig} A$ in the serum}

Enzyme linked immunosorbent assay (ELISA) was use ${ }^{10}$ in all studies. Positive and negative controls were systematically included. Normal values defined by mean ( 2 standard deviations) were calculated from 100 blood donors serum specimens.

Measurement of $\operatorname{Ig} A 1$ and $\operatorname{Ig} A 2$ subclass Serum samples were tested for IgA1 and IgA2 subclass with specific monoclonal antibodies $^{11}$ using a technique adapted from Conley et al. ${ }^{12}$ For IgA1 subclass measurement, mouse monoclonal IgG to human IgA1 (Becton Dickinson, Mountain View, CA, USA) were directly coated on polystyrene Microwell immuno-Nunc plates (Nunc, Kamstrup, Roskilde, Denmark) at a concentration of $3 \mu \mathrm{g} / \mathrm{ml}$ in $0.1 \mathrm{M}$ carbonate buffer pH 9.6 overnight at $4^{\circ} \mathrm{C}$. For IgA2 subclass measurement, plates were coated with goat polyclonal IgG to mouse $\gamma$ chain (Cappel Lab, Cochranville, PA, USA) at a concentration of $20 \mu \mathrm{g} / \mathrm{ml}$ in the previous buffer. After washing, mouse monoclonal IgG to human IgA2 (Becton Dickinson) were added at a concentration of $1 \mu \mathrm{g} / \mathrm{ml}$ in $0.05 \mathrm{M}$ phosphate buffer containing $0.05 \%$ TWEEN 20 and $0.1 \%$ bovine serum albumin $\mathrm{pH} 7 \cdot 3$, incubated for one hour at $37^{\circ} \mathrm{C}$, and then washed three times. Serum samples diluted $1 / 5000$ for IgA1 and IgA2 assays in the same buffer were added in triplicate and incubated 
for one hour at $37^{\circ} \mathrm{C}$ and then plates were washed three times. Peroxidase conjugated goat polyclonal IgG to human $\alpha$ chain diluted $1 / 25000$ in the previous buffer were incubated for one hour at $37^{\circ} \mathrm{C}$. Enzyme activity was detected by the addition to each well of $100 \mu$ l substrate solution consisting of $4 \mathrm{mM}$ orthophenylene diamine (Sigma, Saint-Louis, USA) in $0.02 \mathrm{M}$ citrate phosphate buffer $\mathrm{pH} 5$ containing $0.04 \%$ hydrogen peroxide. After 10 minutes at room temperature, $50 \mu \mathrm{l}$ of $1 \mathrm{~N} \mathrm{HC1}$ were added to stop the reaction. Absorbance of each well was read at $492 \mathrm{~nm}$ with a Titertek Multiskan (Flow Lab, Irvine, UK). Serum samples were tested in the presence of serial dilutions of a pool of serum from 100 normal blood donors. The amounts of $\operatorname{IgA} 1(2 \mathrm{~g} / \mathrm{l})$ and of $\operatorname{IgA} 2$ $(0.2 \mathrm{~g} / \mathrm{l})$ in the pool were determined using standard batch $n^{\circ} 5286$ kindly donated by $\mathrm{Dr}$ J Radl (TNO Institute of Ageing and Vascular Research, Leiden, The Netherlands). Result were expressed as $\mathrm{g} / \mathrm{l}$.

Measurement of secretory Ig $A$ - Plates were coated with $\mathrm{F}\left(\mathrm{ab}^{\prime}\right)_{2}$ fragments of goat polyclonal IgG to human secretory component (kindly provided by $\mathrm{Cl}$ Vincent, INSERM U80, Lyon, France) at a concentration of 20 $\mu \mathrm{g} / \mathrm{ml}$. Serum samples diluted $1 / 200$ were added in triplicate for one hour at $37^{\circ} \mathrm{C}$ and then incubated with peroxidase conjugated goat IgG to human $\alpha$ chain. ${ }^{13}$ Samples were tested in the presence of serial dilutions of human secretory IgA standard (Cappel). Results were expressed as $\mu \mathrm{g} / \mathrm{ml}$.

\section{Detection of $\operatorname{Ig} A$ and $\operatorname{Ig} G$ activity to dietary antigens}

Measurements of $\operatorname{Ig} A$ and $\operatorname{IgG}$ to gliadin Plates were coated overnight at $4{ }^{\circ} \mathrm{C}$ with crude gliadin (Sigma), dissolved in ethanol $70 \%$, and diluted at a concentration of $10 \mu \mathrm{g} / \mathrm{ml}$ in 0.1 $\mathrm{M}$ carbonate buffer $\mathrm{pH} 9 \cdot 6$. Uncoated sites were saturated with a solution of gliadin at $2 \%$ in carbonate buffer for one hour at $37^{\circ} \mathrm{C}$. Serum samples diluted $1 / 50$ for IgA and $1 / 100$ for IgG in $0.05 \mathrm{M}$ phosphate buffer $\mathrm{pH} 7.3$ containing $1 \%$ of rabbit serum (free of gliadin antibody) and $0.05 \%$ TWEEN 20 were added in triplicate for one hour at $37^{\circ} \mathrm{C}$. After washing, plates were incubated with peroxidase conjugated goat polyclonal IgG to human $\alpha$ chain as previously described or with peroxidase conjugated goat to polyclonal IgG to human $\gamma$ chain diluted $1 / 50000$ in the previous buffer.

Measurement of $\operatorname{Ig} A$ and $\operatorname{Ig} G$ to $B S A$ - The above procedure was used except that BSA (Sigma) was directly coated after dilution at a concentration of $10 \mu \mathrm{g} / \mathrm{ml}$ in $0.1 \mathrm{M}$ carbonate buffer $\mathrm{pH} 9 \cdot 6$. Uncoated sites were saturated with a solution of BSA at $5 \%$. Serum samples were diluted $1 / 100$ for IgA and $1 / 200$ for IgG in phosphate buffer $\mathrm{pH} 7 \cdot 3$ containing $1 \%$ rabbit serum free of antibody to BSA and 0.05\% TWEEN 20.

Measurement of IgA and IgG to casein - The above procedure was used except that casein (Sigma) was dissolved in $\mathrm{NaOH} 0.1 \mathrm{~N}$ and then diluted at a concentration of $10 \mu \mathrm{g} / \mathrm{ml}$ in $0 \cdot 1 \mathrm{M}$ carbonate buffer $\mathrm{pH} 9 \cdot 6$ for coating. Uncoated sites were saturated with a solution of casein at $2 \%$. Serum samples were diluted $1 / 200$ for IgA and $1 / 400$ for IgG in phosphate buffer containing $1 \%$ rabbit serum free of antibody to casein and 0.05\% TWEEN 20 .

In the three previous assays, serum samples were tested in the presence of serial dilutions of a pool containing samples with antibody to gliadin, BSA or casein (positive pool). The optical density for each serum sample was expressed as a percentage of the positive pool at the same dilution from a standard straight line. The pool containing serum samples from normal controls was itself tested as an individual serum in the assay and results were expressed as the ratio between the tested serum and this normal pool.

Detection of $\operatorname{Ig} A$ and $\operatorname{IgG}$ activity to non-dietary antigens

Measurement of $\operatorname{Ig} A$ and $\operatorname{IgG}$ to cytomegalovirus - IgA and IgG activity to cytomegalovirus was determined by a sandwich type ELISA and previously described in detail. ${ }^{14}$

Cytomegalovirus specific IgG antibodies were detected by a commercial antibody capture ELISA (Wellcome Laboratories, Dartford, England). Cytomegalovirus specific IgG seriology was performed by a sandwich type ELISA: briefly, F (ab')2 fragments of goat polyclonal IgG to human $\alpha$ heavy chain (Cappel) were used as solid phase capture reagents. After incubation with appropriately diluted samples, the presence of IgA antibodies to cytomegalovirus was shown by addition of peroxidase conjugated purified cytomegalovirus (Wellcome Laboratories, Dartford, England). Serum specimens with absorbance $<0 \cdot 200$ at the $1 / 16$ dilution were considered as negative.

Measurement of IgA and IgG to tetanus toxoidPlates were coated overnight at $4^{\circ} \mathrm{C}$ with tetanus toxoid $(500 \mathrm{Lf} / \mathrm{mg}$ ) (Institute Pasteur, Paris, France) at a concentration of $10 \mu \mathrm{g} / \mathrm{ml}$ in $0 \cdot 1 \mathrm{M}$ carbonate buffer $\mathrm{pH} 9 \cdot 6$. Uncoated sites were blocked with a solution of gelatin at $2 \%$ in carbonate buffer for one hour at $37^{\circ} \mathrm{C}$. Serial twofold dilutions of serum specimens in $0.05 \mathrm{M}$ phosphate buffer $\mathrm{pH} 7.3$ containing 0.05 TWEEN 20 and $0 \cdot 1 \%$ BSA were added in triplicate for one hour at $37^{\circ} \mathrm{C}$. After washing, plates were incubated with peroxidase conjugated goat polyclonal IgG to human $\alpha$ chain or to human $\gamma$ chain as previously described.

The titre was taken as the highest serum dilution that gave an optical density twice as great as the background. ${ }^{15}$

\section{STATISTICAL ANALYSIS}

Results in hyper IgA group were compared with those in the normal IgA group by the Mann-Whitney $U$ test. The relation between total IgA, both IgA subclass concentrations, and IgA activity to dietary antigens with secretory IgA concentration were studied in each patient by the Spearman rank correlation test. 

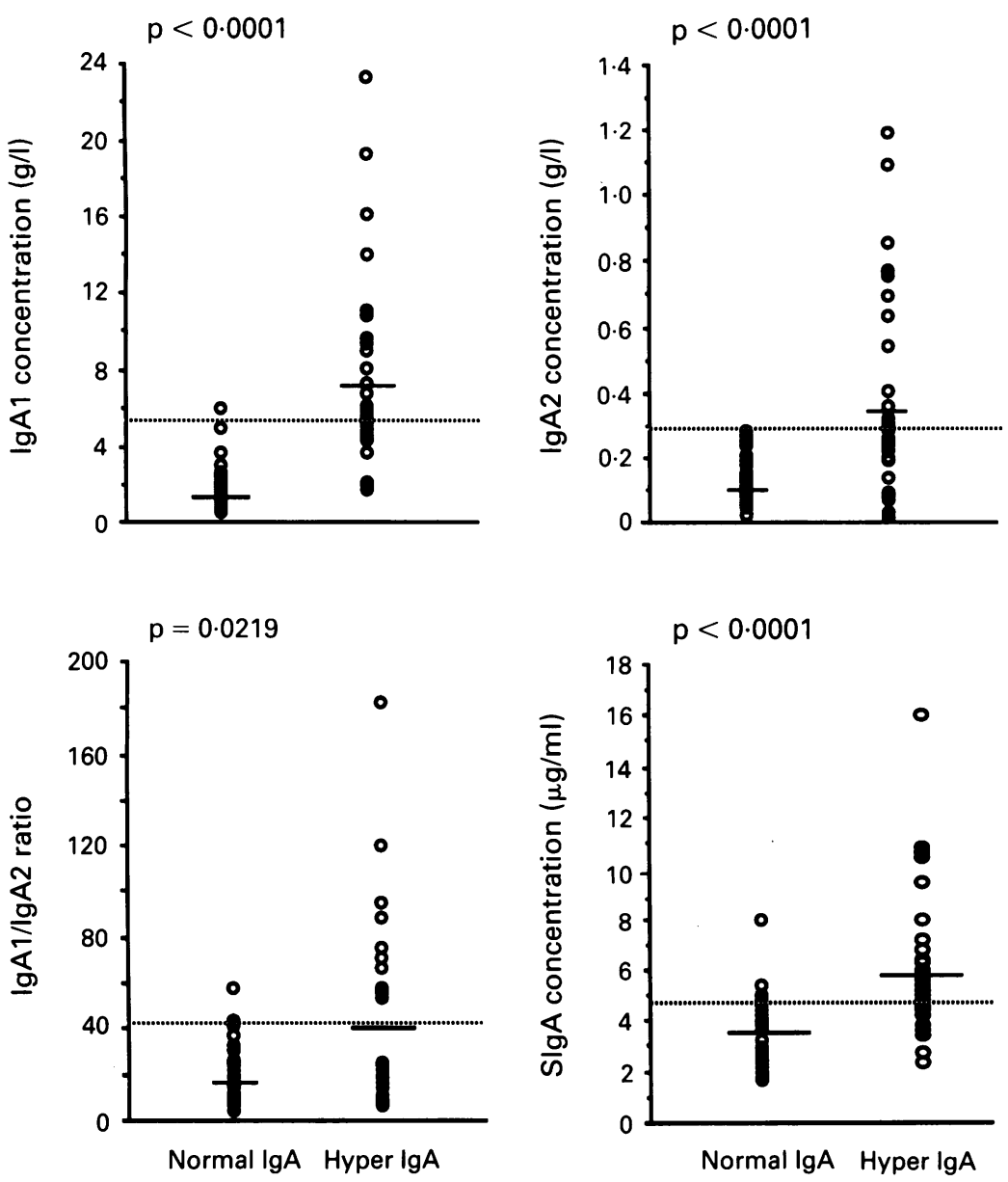

Figure 1: Serum IgA1 and IgA2 subclass and secretory $\operatorname{Ig} A$ concentration and $\operatorname{Ig} A 1 / \operatorname{Ig} A 2$ ratio depending on total $\operatorname{Ig} A$ concentration. Mean value of each group is shown by an unbroken line. Dotted line represents the threshold of increase (mean (2 SD)) from 100 normal controls. IgA1, IgA2, SIgA concentration, and $\operatorname{Ig} A 1 / \operatorname{Ig} A 2$ ratio were very significantly increased in hyper IgA patients compared with the normal IgA patient group by Mann-Whitney $U$ test.
MEASUREMENT OF IgA AND IgG ACTIVITY TO DIETARY ANTIGENS

To study the specificity of $\operatorname{IgA}$ and $\operatorname{IgG}$ to dietary antigens in patients with hyper IgA in comparison with patients with normal IgA concentrations, IgA and IgG activity to gliadin, BSA, and casein were measured in the serum. Anti-gliadin IgA activity index was $6.38(10.9)$ in the hyper IgA group and 1.38 $(0 \cdot 73)$ in the normal IgA group $(\mathrm{p}<0.0001)$. Anti-BSA IgA activity index was $1 \cdot 88(1 \cdot 14)$ in the hyper IgA group and $1.32(0.6)$ in the normal IgA group $(p=0 \cdot 0016)$. Anti-casein IgA activity index was $1.64(1.87)$ in the hyper IgA group and $0.98(0.45)$ in the normal IgA group ( $p=0.0033$ ) (Fig 3). IgA activity to the three dietary antigens selected were significantly increased in hyper $\operatorname{IgA}$ patients.

An attempt was made to find a relation between the anti-dietary IgA activity and the secretory IgA concentration in the serum. A very significant correlation could be shown between secretory IgA and IgA to gliadin $(r=0.82 ; \mathrm{p}<0.0001)$, IgA to BSA $(r=0.59$; $\mathrm{p}<0.0001)$, and IgA to casein $(r=0.44$; $\mathrm{p}<0.0001$ ) (Fig 2).

By contrast, no significant difference was found for IgG activity to the three dietary antigens between the hyper IgA and normal IgA group. Anti-gliadin IgG activity index was $2.12(1.99)$ in the hyper IgA group and 1.32 $(0.46)$ in the normal IgA group $(p=0.097)$. Anti-BSA IgG activity index was respectively $2 \cdot 21(1.39)$ and $2.05(1.53)(p=0.4351)$. Anticasein IgG activity index was respectively 1.00 $(0.53)$ and $0.95(0.72)(\mathrm{p}=0.2166)$.

MEASUREMENT OF PREVIOUS PARAMETERS IN RELATION TO CD4 + CELLS NUMBER CD4 + cell number in the peripheral blood was expressed in patient groups with normal $\operatorname{IgA}$ and hyper IgA.

In the normal IgA group, $\mathrm{CD} 4+$ cell number was higher than $600 / \mathrm{mm}^{3}$ in 31 patients and lower than $400 / \mathrm{mm}^{3}$ in 14 patients (six with CD4+ cells $<200$ ). In the hyper IgA group, CD4+ cell number was higher than $600 / \mathrm{mm}^{3}$ in seven patients and lower than $400 / \mathrm{mm}^{3}$ in 25 patients (12 with CD4+ cells $<200$ ). There was a significant difference in CD4 + cell number between the two groups $(p<0.0001)$ (Table I).

Values of $\operatorname{IgA} 1 / \operatorname{IgA} 2$ ratio, secretory $\operatorname{IgA}$, IgA to gliadin, BSA, and casein were not increased whatever the CD4+ cell number when the total IgA concentration was normal. They were increased in patients with total hyper IgA. The increase was higher in patients when the number of $\mathrm{CD} 4+$ cells was less than $400 / \mathrm{mm}^{3}$ and higher than $600 / \mathrm{mm}^{3}$ with a significant difference for IgA to BSA $(p=0.02)$, apart from the $\operatorname{Ig} A 1 / \operatorname{Ig} A 2$ ratio, which decreased non-significantly. These results could be only partly explained by the difference in total IgA concentration in hyper IgA patients and a direct relation with immune deficiency stage has to be considered (Table I). 

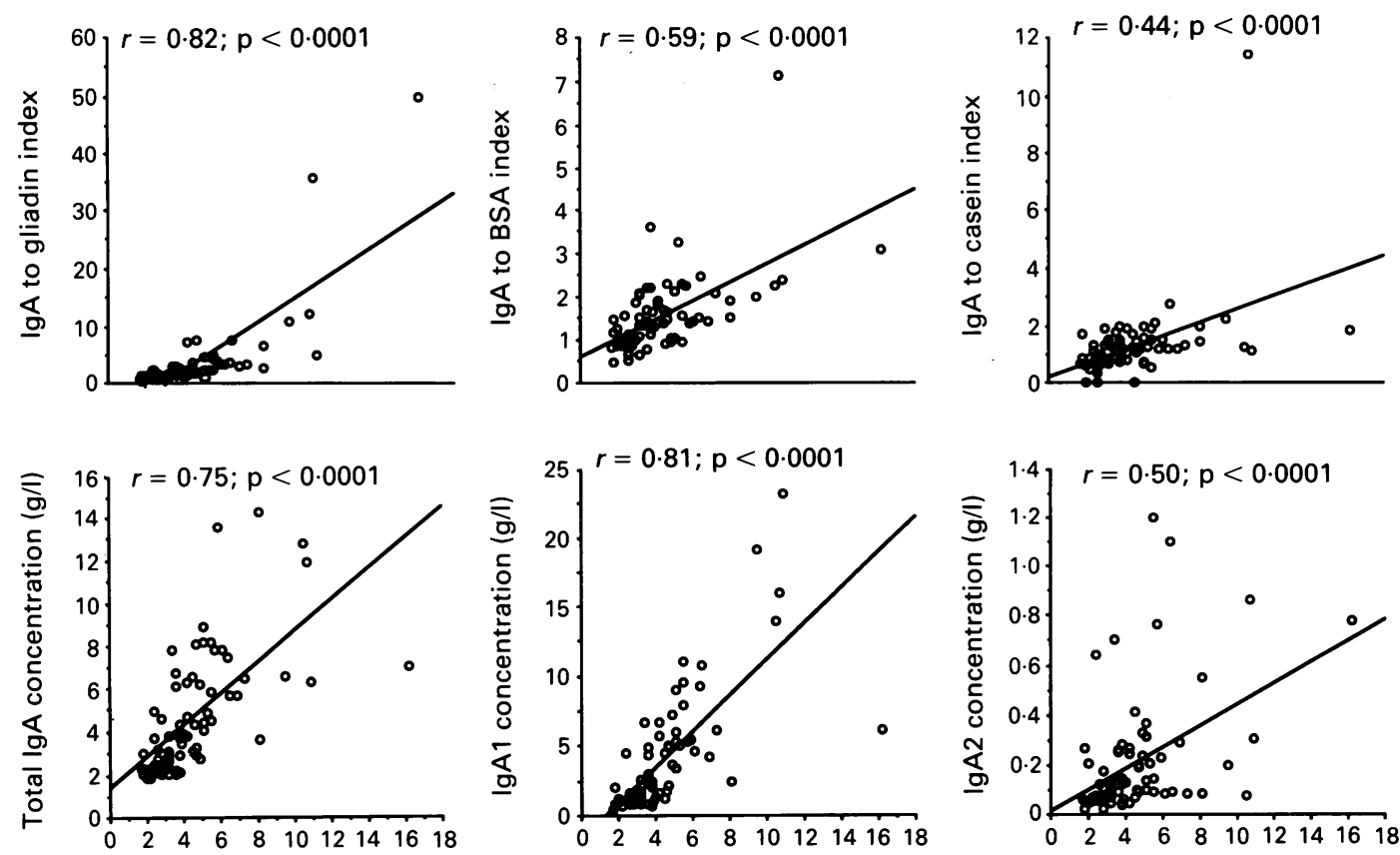

SIgA concentration $(\mu \mathrm{g} / \mathrm{ml})$

SlgA concentration $(\mu \mathrm{g} / \mathrm{ml})$

SIgA concentration $(\mu \mathrm{g} / \mathrm{ml})$

Figure 2: Regression lines of total IgA, both IgA subclass serum concentrations, and $\operatorname{Ig} A$ activity to dietary antigens on secretory IgA activity. Correlation coefficient and significance are shown.

MEASUREMENT OF IgA AND IgG ACTIVITY TO NON-DIETARY ANTIGENS

In an attempt to examine the specificity to antigens that were not gut derived, IgA and IgG antibodies to cytomegalovirus and to tetanus toxoid were measured in the serum.

IgA antibodies to cytomegalovirus were not detected in any tested subjects. Geometric mean titre of IgG antibodies to cytomegalovirus was 1687 in the hyper $\operatorname{IgA}$ group and 2336 in the normal IgA group $(p=0.3906)$.

IgA antibodies to tetanus toxoid were detected with titres higher than 10 (from 10 to
$40)$ in five of 45 patients $(11 \cdot 1 \%)$ in the normal IgA group and one of 32 patients $(3 \cdot 1 \%)$ in the hyper IgA group (Table II). The difference was not significant $(p=0 \cdot 4751)$. IgG antibodies to tetanus toxoid were detected in all subjects with geometric mean titre 1018 in the hyper IgA group and 990 in the normal IgA group $(p=0 \cdot 7211)$.

\section{Discussion}

This study, performed in HIV1 infected patients, classified according to the IgA
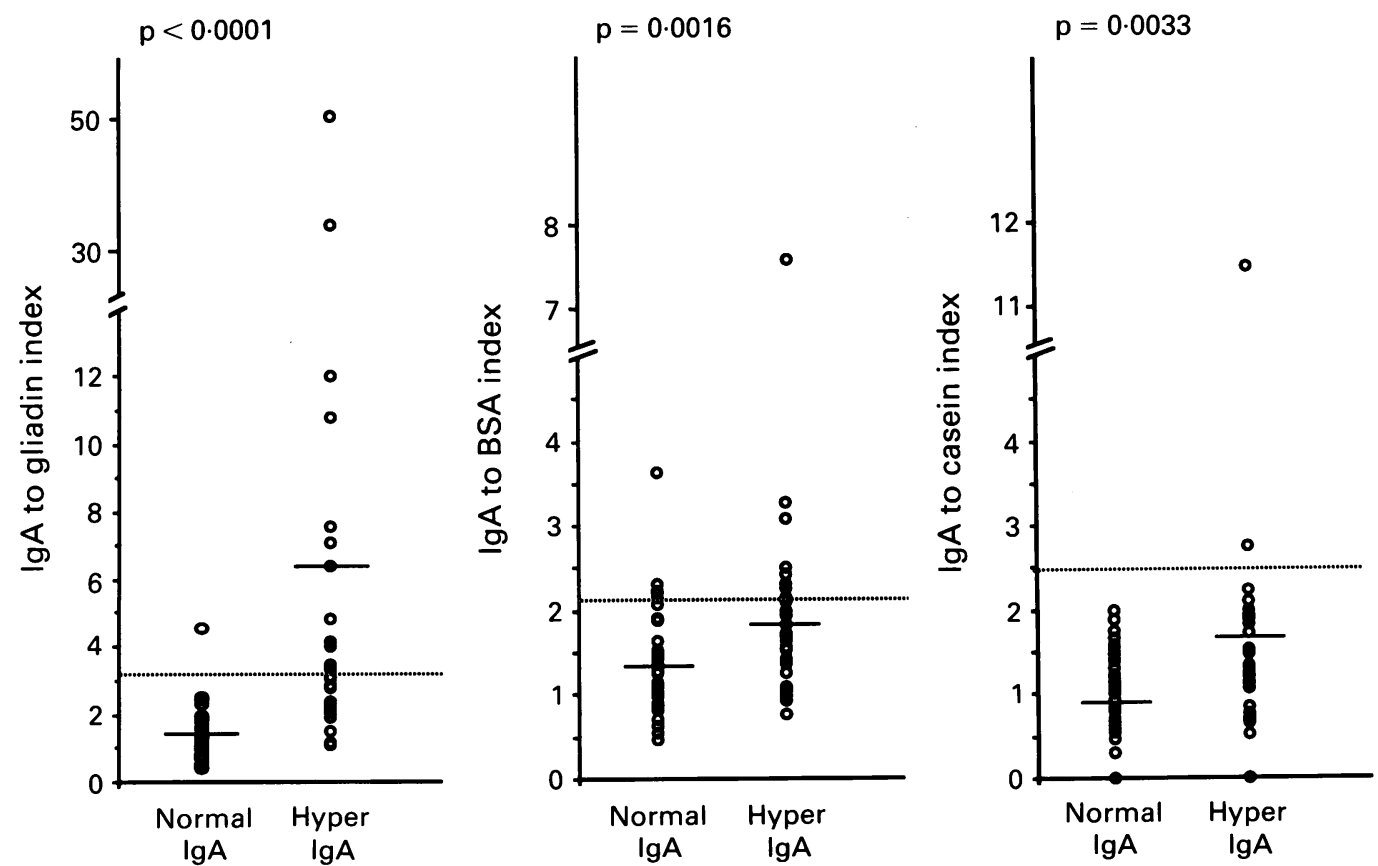

Figure 3: Serum anti-dietary antigen IgA activity concentration depending on total IgA concentration. Mean value of each group is shown with an unbroken line. Dotted line represents the threshold of increase (mean (2 SD)) from 100 normal controls. IgA to gliadin, to $B S A$, and to casein activity were very significantly increased in hyper IgA patients compared with the normal IgA patient group by Mann-Whitney $U$ test. 
TABLE I Structure and anti-dietary specificity of serum IgA depending on CD4+ cell number

\begin{tabular}{|c|c|c|c|c|c|c|c|c|}
\hline & $\begin{array}{l}\text { CD4+ cells } \\
\left(\mathrm{n} / \mathrm{mm}^{3}\right)\end{array}$ & $\begin{array}{l}\text { Patients } \\
\text { (n) }\end{array}$ & $\begin{array}{l}\text { Total IgA } \\
(\mathrm{g} / \mathrm{l})\end{array}$ & $\begin{array}{l}\operatorname{Ig} A 1 / \operatorname{Ig} A 2 \\
\text { (ratio) }\end{array}$ & $\begin{array}{l}S I g A \\
(\mu g / m l)\end{array}$ & $\begin{array}{l}\text { IgA to gliadin } \\
\text { (index) }\end{array}$ & $\begin{array}{l}\text { IgA to } B S A \\
\text { (index) }\end{array}$ & $\begin{array}{l}\text { IgA to casein } \\
\text { (index) }\end{array}$ \\
\hline $\begin{array}{c}\text { Normal IgA } \\
(n=45) \\
\text { Hyper IgA } \\
(n=32)\end{array}$ & $\begin{array}{l}>600 \\
<400 \\
>600 \\
<400\end{array}$ & $\begin{array}{r}31 \\
14 \\
7 \\
25\end{array}$ & $\begin{array}{l}2 \cdot 7(0 \cdot 62) \\
3 \cdot 08(0 \cdot 7) \\
6 \cdot 84(3 \cdot 37) \\
7 \cdot 26(2 \cdot 48)\end{array}$ & $\begin{array}{l}17 \cdot 35(9 \cdot 79) \\
21 \cdot 38(14 \cdot 43) \\
53 \cdot 48(40 \cdot 10) \\
36 \cdot 51(40 \cdot 16)\end{array}$ & $\begin{array}{l}3.30(1.21) \\
3 \cdot 15(1.00) \\
4 \cdot 74(1.33) \\
6.44(3.07)\end{array}$ & $\begin{array}{l}1 \cdot 36(0 \cdot 79) \\
1.42(0 \cdot 6) \\
2.92(2 \cdot 15) \\
7 \cdot 35(11 \cdot 22)\end{array}$ & $\begin{array}{l}1.26(0.68) \\
1.44(0.35) \\
1.29(0.57) \\
2.04(1.21)^{\star}\end{array}$ & $\begin{array}{l}0.92(0.47) \\
1.12(0.39) \\
1.15(0.77) \\
1.78(2.07)\end{array}$ \\
\hline
\end{tabular}

Results are expressed as mean (SD); ${ }^{\star} \mathrm{p}=0.02$ by Mann-Whitney $\mathrm{U}$ test comparing patients with hyper IgA according to CD4+ cell number.

concentration in the serum, confirms the relation between the increase of serum IgA concentration and the decrease of CD4+ cell number. This is in contrast with the IgG concentration, which increases very early and the IgM concentration, which does not increase during the course of HIV disease (unpublished data). ${ }^{2}$ This discrepancy between circulating immunoglobulins concentrations of different classes suggests that polyclonal activation of B cell may not be the only mechanism responsible for the hyper IgA seen in the serum. ${ }^{3}$

As it was considered that serum IgA concentration could be related to mucosal immune system stimulation, ${ }^{16}$ IgA structural characteristics and anti-dietary antigen IgA activity were studied. By comparison with patients with normal IgA, IgA1 and IgA2 subclass concentrations were both found increased in the serum of hyper IgA patients with a good correlation but the increase of IgA1 was predominant. The highly significant increase of secretory IgA and of IgA antibody activity to gliadin and at a lower activity to BSA and casein correlated with secretory IgA concentration in the serum of hyper IgA patients. This provides strong evidence for the presence of circulating secretory IgA with anti-dietary antigen activity in these patients. All the parameters varied according to the total IgA concentration but were also directly related to the stage of the immune deficiency in patients with hyper IgA. By contrast, IgG activity to dietary antigens was not increased and IgA antibodies to non-gut derived antigens like cytomegalovirus or tetanus toxoid was not detected or was very low whatever the total IgA concentration.

A study analysing subclass distribution, showed that an increase of total serum $\operatorname{IgA}$ was accompanied by a preferential increase of IgA1 in connective tissue diseases and to lesser extent in Berger's disease and chronic active liver disease whereas IgA2 percentages tended to be higher in alcoholic cirrhosis and Crohn's disease. ${ }^{17}$ Serum concentration of secretory IgA was found increased in lactating women, Crohn's disease, and especially in liver diseases. ${ }^{18}$

TABLE II Frequency of $\operatorname{Ig} A$ antibodies to tetanus toxoid with regard to total $\mathrm{Ig} A$ concentration

\begin{tabular}{lllll}
\hline & \multicolumn{4}{l}{$\begin{array}{l}\text { No of patients (\%) with IgA antibodies to } \\
\text { tetanus toxoid titres }\end{array}$} \\
\cline { 2 - 5 } & $<10$ & 10 & 20 & 40 \\
\hline $\begin{array}{c}\text { Normal IgA } \\
(\mathrm{n}=45)\end{array}$ & $40(88 \cdot 9)$ & $1(2 \cdot 22)$ & $2(4 \cdot 44)$ & $2(4 \cdot 44)$ \\
$\begin{array}{c}\text { Hyper IgA } \\
(\mathrm{n}=32)\end{array}$ & $31(96 \cdot 9)$ & $0(0)$ & $0(0)$ & $1(3 \cdot 1)$ \\
\hline
\end{tabular}

Results expressed as mean (SD).
High titres of antigliadin IgA antibody in the serum has classically been considered as distinctive of the intolerance to gliadin seen in susceptible subjects with coeliac disease. ${ }^{19}$

An increased proportion of polymeric IgA and of secretory $\operatorname{IgA}$ to gliadin has also been described ${ }^{20}$ with a predominance of IgA1 isotype in this disease. ${ }^{21}$

It was shown, however, that serum concentration of IgA antibodies to other dietary antigens are often increased in these patients. ${ }^{22}$ Moreover high titres of antigliadin IgA antibody and to other dietary antigens were occasionally detected in Crohn's disease, ulcerative colitis, food allergy, and also in Sjögren's syndrome, rheumatoid arthritis and in Berger's disease. ${ }^{23}$ Sensitive methods permit even the detection of these antibodies at low titre in normal subjects. ${ }^{24}$

Enteropathy has been shown to be associated with AIDS. ${ }^{25}$ Gastrointestinal manifestations are common. ${ }^{26}$ In some patients, diarrhoea has been shown to result from specific infectious agents ${ }^{8}$ but in others no such course is evident and a direct cytopathogenic effect of HIV itself ${ }^{9}$ or an indirect local immune mechanism ${ }^{27}$ is suspected. Structural and functional changes, such as low grade bowel atrophy with hyporegeneration, may result from the loss of activated regulatory $\mathrm{T}$ cells in the mucosa. ${ }^{28} \mathrm{~A}$ reduced number of intestinal IgA containing plasma cells has been reported in AIDS patients. ${ }^{29}$ Decreased brush border enzyme activities can be found in patients with AIDS $^{30}$ but also early in the course of HIV infection ${ }^{6}$ causing a malabsorption. ${ }^{31}$

All these data argue in favour of a nonspecific immunological hyper-responsiveness against antigens present in the gut lumen probably associated with an increased mucosal permeability resulting from abnormal small intestinal mucosa in HIV infected patients. ${ }^{72}$ Respiratory or genitourinary tract mucosa can also participate in the hyperproduction of IgA. Impaired clearance of SIgA remains an alternative mechanism. ${ }^{17}$ The increased concentration of polymeric or monomeric IgA in the serum of HIV1 infected patients is controversial. ${ }^{33} 34$ The original of serum secretory IgA antibodies and of IgA to dietary antigens has to be elucidated. They may represent antibodies produced locally in the gut mucosa spilling over into the circulation ${ }^{20}$ or they may be produced in the bone marrow and in extraintestinal lymphoid tissue as the result of the migration of locally stimulated lymphocytes, or both ${ }^{35}$ or result from uptake of luminal antigens into the blood. ${ }^{36}$ 
This study strongly suggests a disturbance of the gut mucosal immunity increasing during the course of HIV infection as partly responsible for the hyper IgA seen but probably also responsible for other immunological abnormalities and for a defect in the antiinfectious defence mechanisms.

This work was presented in part at the Joint meeting of the British Society of Immunology and Société Française d'Immunologie - London, October 1991.

We wish to thank F Duplat for technical assistance and E Gagnaire for secretarial assistance. This work was supported by a grant of 'Fondation Mérieux' and a grant of 'Région PhôneAlpes'.

1 Pahwa SG, Quilop MTJ, Lange M, Pahwa RN, Grieco MH. Defective N-lymphocyte function in homosexual men in relation to the acquired immunodeficiency syndrome. Ann Intern Med 1984; 101: 757-63.

2 Fahey JL, Taylor JMG, Detels R, Hofmann B, Melmed R, Nishanian $\mathrm{P}$, et al. The prognostic value of cellular and serologic markers in infection with human immunodeficincy virus type 1 . $N$ Engl f Med 1990; 322: 166-72.

3 Lane HC, Masur H, Edgar LC, Whalen G, Rook AH, Fauci AS. Abnormalities of B-cell activation and immunoregulation in patients with the acquired immunodeficiency lation in patients with the acquired imm

4 Yarchoan R, Redfield RR, Broder S. Mechanisms of B cell activation in patients with acquired immunodeficiency syndrome and related disorders. Contribution of antibody-producing B cells, of Epstein-Barr virus-infected B cells, and of immunoglobulin production induced by human $\mathrm{T}$ cell lymphotropic virus, type III/ymphadenopathy-associated virus. $\mathcal{f}$ Clin Invest 1986; 78: 439-47.

5 Schnittman SM, Lane HC, Higgins SE, Folks T, Fauci AS. Direct polyclonal activation of human B lymphocytes by the acquired immune deficiency syndrome virus. Science 1986; 233: 1084-6.

6 Ullrich R, Zeitz M, Heise W, L'age M, Höffken G, Riecken EO. Small intestinal structure and function in patients infected with human immunodeficiency virus (HIV): infected with human immunodeficiency virus (HIV): 1989; 111: 15-21.

7 Lim Seng G, Menzies IS, Lee CA, Johnson MA, Pounder RE. Small intestinal permeability in HIV positive patients. In: VII International conference on AIDS. [Abstract]. Florence: 1991; 1: 245.

8 Laughon BE, Druckman DA, Vernon A, Quinn TC, Polk $\mathrm{F}$, Modlin JF, et al. Prevalence of enteric pathogens in homosexual men with and without acquired immunodeficiency syndrome. Gastroenterology 1988; 94: 984-93.

9 Nelson JA, Wiley CA, Reynolds-Kohler C, Reese CE, Mergaretten W, Levy JA. Human immunodeficiency virus detected in bowel epithelium from patients with gastrointestinal symptoms. Lancet 1988; i: 259-62.

10 Engwall E. Enzyme immunoassay: ELISA and EMIT. Methods Enzymol 1980; 70: 419-22.

11 Engström PE, Norhagen G, Smith CIE, Söder PO, Engström PE, Norhagen G, Smith CIE, Söder PO, Hammarström L. An enzyme-linked immunosorbent assay for the determination of the IgA subclass distribution of antigen-sp

12 Conley ME, Arbeter A, Douglas SD. Serum levels of IgA1 and IgA2 in children and in patients with IgA deficiency. Mol Immunol 1983; 20: 977-81.

13 Vincent C, Revillard JP. Sandwich-type ELISA for free and bound secretory component in human biological fluids. $\mathcal{F}$ Immunol Methods 1988; 106: 153-60.

14 Quesnel A, Pozzetto B, Touraine F, Moja P, Lucht F, De The G, et al. Antibodies to Epstein-Barr virus and Cytomegalovirus in relation to $\mathrm{CD} 4$ cell number in human immunodeficiency virus 1 infection. $f$ Med Virol 1992; 36: 60-4.

15 Ballet J, Sulcebe G, Couderc LJ, Danon F, Rabian C, Lathrop $\mathrm{M}$, et al. Impaired anti pneumococcal antibody response in patients with AIDS-related persistent generalized lymphadenopathy. Clin Exp Immunol 1987; 68: 479-87.
16 Conley ME, Delacroix DL. Intravascular and mucosal immunoglobulin A: two separate but related systems of immune defense? Ann Intern Med 1987; 106: 892-9.

17 Delacroix DL, Elkon B, Geubel AP. Hodgson HF, Dive C, Vaerman JP. Changes in size, subclass, and metabolic properties of serum immunoglobulin $\mathrm{A}$ in liver diseases and in other diseases with high serum immunoglublin A. $\mathcal{f}$ Clin Invest 1983; 71: 358-67.

18 Delacroix D, Vaerman JP. Reassessment of levels of secretory IgA in pathological sera using a quantitative radioimmunoassay. Clin Exp Immunol 1981; 43: 633-40.

19 Savilahti E, Perkkiö M, Kalimo K. Viander M, Vainio E, Reunala T, IgA antigliadin antibodies: a marker of mucosal damage in childhood coeliac disease. Lancet 1983; i: 320-2.

20 Mascart-Lemone F, Cadranel S, Van den Broeck J, Dive C, Vaerman JP Duchateau J. IgA immune response patterns to gliadin in serum. Int Arch Allergy Appl Immunol 1988; to gliadin in

21 Volta U, Molinaro N, Fratangelo D, Bianchi FB. IgA subclass antibodies to gliadin in serum and intestinal juice of patients with coeliac disease. Clin Exp Immunol 1990; 80: $192-5$.

22 Scott H, Fausa O, Ek J, Brandtzaeg P. Immune response patterns in coeliac disease. Serum antibodies to dietary antigens measured by an enzyme linked immunosorbent assay (ELISA). Clin Exp Immunol 1984; 57: 25-32.

23 Troncone R, Ferguson A. Anti-gliadin antibodies. F Pediatr Gastroenterol Nutr 1991; 12: 150-8.

24 Grodzinsky E, Hed J, Lieden G, Sjögren F, Ström M. Presence of IgA and IgG antigliadin antibodies in healthy
adults as measured by micro-ELISA. Int Arch Allergy Appl Immunol 1990; 92: 119-23.

25 Kotler DP, Gaetz HP, Lange M, Klein EB, Holt PR. Enteropathy associated with the acquired immuno-

deficiency syndrome. Ann Intern Med 1984; 101: 421-8.
26 Dworkin B, Wormser GP, Rosenthal WS, Heier SK, Braunstein $M$, Weiss $L$, et al. Gastrointestinal manifestations of the acquired immunodeficiency syndrome: a review of 22 cases. Am $\mathcal{F}$ Gastroenterol 1985; 80: 774-8.

27 Zeitz M, Ullrich R, Riecken EO. The role of the gutassociated lymphoid tissue in the pathogenesis of the acquired immunodeficiency syndrome (HIV-infection). In: Proceeding of the Fifth International Congress of Mucosal Immunology London: Kluwer Academic, 1990. 655-9.

28 Ullrich R, Zeitz M, Heise W, L'age M, Ziegler K, Bergs C, et al. Mucosal atrophy is associated with loss of activated $\mathrm{T}$ cells in the duodenal mucosa of human immunodeficiency virus (HIV)-infected patients. Digestion 1990; 46 (suppl 2): 302-7.

29 Kotler DP, Scholes JV, Tierney AR. Intestinal plasma cell alterations in acquired immunodeficiency syndrome. Dig Dis Sci 1987; 32: 129-38.

30 Cummins AG, La Brooy JT, Stanley DP, Rowland R, Shearman DJC. Quantitative histological study of enteropathy associated with HIV infection. Gut 1990; 31: 317-21.

31 Gillin JS, Shike M, Alcock N, Urmacher C, Krown S, Kurtz $\mathrm{RC}$, et al. Malabsorption and mucosal abnormalities of the small intestine in the acquired immunodeficiency syndrome. Ann Intern Med 1985; 102: 619-22.

32 Batash S, Weinshel E, Falkenstein D, Ma T, Katz K, Hollander $\mathrm{D}$, et al. HIV infection increases intestinal permeability. Am $\mathcal{f}$ Gastroenterol 1991; 86: 1344 .

33 Vincent C, Cozon G, Zittoun M, Mellquist M, Kazatchkine $\mathrm{MD}$, Czerkinsky C, et al. Secretory immunoglobulins in $\mathrm{MD}$, Czerkinsky C, et al. Secretory immunoglobulins in serum from

34 Kozlowski PA, Jackson S. Serum IgA subclasses and molecular forms in HIV infection: selective increases in monomer and apparent restriction of the antibody response to IgAl antibodies mainly directed at env glycoproteins. AIDS Res Hum Retroviruses 1992; 8: 1773-80.

35 McCaughan GW, Adams E, Basten A. Human antigenspecific IgA responses in blood and secondary lymphoid tissue: an analysis of help and suppression. F Immunol 1984; 132: 1190-6.

36 Paganelli R, Levinsky RJ, Atherton DJ. Detection of specific antigen within circulating immune complexes: validation of the assay and its application to food antigen-antibody complexes formed in healthy and food-allergic subjects. Clin Exp Immunol 1981; 46: 44-53. 